\title{
Effects of tramadol and acepromazine on intraocular pressure and pupil diameter in young healthy cats
}

\author{
Deise Cristine Schroder ${ }^{1}$ \\ Bianca Garay Monteiro ${ }^{1}$ Deborah Braga Pytlak ${ }^{1}$ \\ Mayara Carvalho de Souza \\ Adriane Jorge Mendonça ${ }^{1}$ Alexandre Pinto Ribeiro ${ }^{1}$
}

'Faculdade de Medicina Veterinária (FAVET), Universidade Federal do Mato Grosso (UFMT), Cuiabá, MT, Brasil. E-mail: alexandre.aleribs@gmail. com. ${ }^{*}$ Corresponding author.

\begin{abstract}
This study aimed to investigate the effects of the systemic administration of acepromazine, tramadol and the association of both on intraocular pressure (IOP) and pupil diameter (PD) in young healthy cats. Cats were randomly allocated into three groups $(n=10 /$ each) and intramuscular acepromazine $(A G)$, tramadol $(T G)$ or acepromazine combined with tramadol $(A T G)$ were injected. PD (electronic caliper) and IOP (applanation tonometry) were assessed before (baseline) and following 15, 30, 60, and 120 minutes of treatments. It was verified that in $A G, P D$ decreased significantly from time point 30 to 120 ( $P=0.002)$, but such reduction did not differ significantly from baseline $(P=0.89)$. In $T G, P D$ increased significantly from the first 15 minutes, until the last time point of evaluation $(P<0.001)$. In $A T G$, $P D$ increased significantly from time point 30 to 120 when compared to baseline $(P<0.001)$; but significant differences from time point 30 to 120 were not seen $(P=0.71)$. Comparisons among groups showed that $P D$ values of $T G$ and $A T G$ were significantly higher than that of $A G(P<0.05)$. IOP values, on the other hand, did not change significantly among time points and groups $(P>0.05)$. It can be concluded that tramadol alone or in association with acepromazine produced significant mydriasis for up to 120 minutes, without changing IOP values in normal cats. Results of this study suggested that tramadol alone or in association with acepromazine caused significant mydriasis and did not change IOP values in normal cats. Therefore, it may be considered a satisfactory pre-anesthetic combination for ophthalmic surgery in cats. However, further studies are warranted on the use of such protocols in cats with ophthalmic diseases undergoing ocular or intraocular surgery.

Key words: opioid, phenothiazinic, mydriasis, intraocular surgeries, cats.
\end{abstract}

Efeitos do tramadol e da acepromazina sobre a pressão intraocular e o diâmetro pupilar em gatos saudáveis jovens

RESUMO: Objetivou-se estudar os efeitos da administração sistêmica da acepromazina, do tramadol e da associação de ambos sobre a pressão intraocular (PIO) e o diâmetro pupilar (DP) em gatos saudáveis jovens. Os gatos foram aleatoriamente distribuídos em três grupos $(n=10 /$ cada) e tratados pela via intramuscular com acepromazina (GA), tramadol $(G T)$ ou acepromazina combinada ao tramadol (GAT). O DP (paquimetria eletrônica) e a PIO (tonometria de aplanação) foram mensurados antes (basal) e após 15, 30, 60, e 120 minutos após a administração dos tratamentos. Constatou-se que no GA, o DP reduziu significativamente a partir do $30^{\circ}$ até o $120^{\circ}$ minuto de avaliação $(P=0.02)$, mas sem diferir significativamente em relação ao basal $(P=0,89)$. No GT, o DP se elevou significativamente desde $15^{\circ}$ minuto, até $o$ último período de avaliação $(P<0.001)$. No GAT, o DP se elevou de forma significativa do $30^{\circ}$ ao $120^{\circ}$ minuto em comparação ao basal $(P<0,001)$, mas esse parâmetro não alterou significativamente do $30^{\circ}$ ao $120^{\circ}$ minuto $(P=0.71)$. Comparações entre os grupos mostraram que o DP do GT e do GAT apresentaram valores significativamente mais elevados que aqueles do $G A(P<0,05)$. A PIO, por sua vez, não se alterou de forma significativa nos periodos e entre os grupos avaliados $(P>0,05)$. Conclui-se que o tramadol, administrado de forma isolada ou em associação à acepromazina, produz midríase de até 120 minutos, sem alterar os valores da PIO em gatos saudáveis. Dessa forma, esse protocolo pré-anestésico pode ser considerado uma alternativa para cirurgia oftálmica em gatos. Todavia, os resultados desse protocolo em gatos com doença oftálmica, que necessitem de cirurgia, devem ser avaliados em estudos futuros.

Palavras-chave: opióide, fenotiazínico, midríase, cirurgias intraoculares, gatos.

\section{INTRODUCTION}

Acepromazine is a phenothiazine widely used in veterinary medicine for its sedative, anti-emetic, and anti-arrhythmogenic properties (STEPHAN et al., 2003; CASSU et al., 2005; STEAGALL et al., 2008). It is known that patients subjected to intraocular surgeries should recover from general anesthesia slowly and smoothly. Considering the long-acting effect of acepromazine, the agent may be used as a preanesthetic medication in surgeries with these purposes (GELATT, 2011).

Tramadol exerts its action through interactions with opioid, serotonin and adrenergic 
receptors (PYPENDOP \& ILKIW, 2008). Nonetheless, the primary metabolite O-demethyl-tramadol (M1) is 2 to 4 times more potent than the parent drug and may account for part of the analgesic effect. (MATOUSKOVA et al., 2011). In dogs and cats, the agent is recommended for management of acute and chronic pain (CAGNARDIet al., 2011; CLARK et al., 2011). Opioids are frequently associated to sedatives in the pre-operative period to potentiate the sedative effects of both agents (STEPHAN et al., 2003). In cats; however, when associated to tramadol, acepromazine does not act synergistically with regard to tranquilization (CASSU et al., 2005). Nevertheless, acepromazine still increases the nociceptive threshold and time of duration of analgesia when associated with tramadol (STEAGALL et al., 2008).

The effects of systemic opioid narcotics on the pupil diameter (PD) vary greatly between species and between classes of mixed opioid and pure opioid agonists (SHARP, 1991; STEPHAN et al., 2003). It has been proven that morphine causes miosis in humans, dogs, and rabbits, and mydriasis in mice, rats, monkeys, and cats (SHARP, 1991; KNAGGS et al., 2004). In humans, PD changes are observed only after 120 minutes of administration of tramadol (KNAGGS et al., 2004; MATOUSKOVA et al., 2011; STOOPS et al., 2013). Lacrimal production, PD, and intraocular pressure (IOP) did not change significantly during 60 minutes of evaluation in dogs treated with different doses of tramadol (SANTOS et al., 2013; RUIZ et al., 2015). Notwithstanding, acepromazine alone or in association with hydromorphone or tramadol causes miosis in dogs (STEPHANet al., 2003, SANTOS et al., 2013).

During corneal and intraocular surgeries, adequate control of PD and IOP is critical to the success of the surgery (GELATT, 2011). Preoperative drugs that increase PD without affecting the IOP should be selected for intraocular surgeries (STEPHAN et al., 2003; GELATT, 2011; RUIZ et al., 2015). Nonetheless, choosing adequate protocols with these purposes may be challenging, once most of analgesic and anesthetic agents change these features (TAMURA et al., 2002; STEPHAN et al., 2003; GELATT, 2011; MAYORDOMO-FEBER et al., 2017). To the author's knowledge, only one study with this purpose has been carried out in normal cats, where MALMASI\&GHAFFARI (2016) reported that intramuscular medetomidine ( $\alpha-2$ agonist) did not cause a statistically significant change in the mean IOP values. Previous studies describing the effects of acepromazine and opioids on PD and IOP in this species have not been published so far. Considering that minimum alveolar concentration of isoflurane is decreased in cats treated pre-operatively with tramadol alone, in addition to the fact that when the agent is associated to acepromazine its antinociceptive effects are potentialized (CAGNARDI et al., 2011; STEAGALL et al., 2008), it is reasonable to investigate the effects of both agents in ophthalmic parameters of cats. Therefore, the present study aimed to evaluate possible changes in PD and IOP of healthy cats treated with acepromazine, tramadol or the association of both drugs.

\section{MATERIALS AND METHODS}

Thirty intact domestic short hair cats of both genders (13 males and 17 females), with average weight and age of $3.3 \mathrm{~kg}$ (range: 2 to $4.3 \mathrm{~kg}$ ) and 1.3 years (range: 6 months to 2 years), respectively, were recruited. Healthy animals were selected if no abnormities were detected on cardiac and respiratory rate, capillary refill time, temperature, skin turgor, Schirmer's tear test, slit lamp biomicroscopy, intraocular pressure, ophthalmoscopy, fluorescein test, bloodwork, and basic chemistry profile. Selected cats were kept in a room with 37 lux luminosity, $70 \%$ of relative humidity, $27^{\circ} \mathrm{C}$ of temperature ${ }^{a}$, were exposed to 12 hours of light/dark cycle, fed with cat dry pellet twice daily, and provided with water ad libitum. After the instillation of one drop of $0.5 \%$ proxymetacaine, horizontal PD was assessed using an electronic caliper ${ }^{\mathrm{b}}$ in the same environment. IOP was assessed by means of applanation tonometry ${ }^{c}$, and only values with less than 5\% standard deviation were considered for statistical analysis. Prior to the beginning of the experiment, all individuals were adapted to the procedures and staff for a period of two days. At day three, baseline PD and IOP were recorded. On all occasions, both parameters were assessed in the right and left eyes, always at 11 a.m. Afterwards, animals were randomly assigned to one of the following groups (10 cats/each). In the first group, cats received $0.05 \mathrm{mg} \mathrm{kg}^{-1}$ of acepromazine (AG). In the second group, cats were treated with $3 \mathrm{mg}$ $\mathrm{kg}^{-1}$ of tramadole (TG), and in the third, a mixture of $0.05 \mathrm{mg} \mathrm{kg}^{-1}$ acepromazine and $3 \mathrm{mg} \mathrm{kg}^{-1}$ of tramadol (ATG) was administered. In all groups, drugs were delivered by intramuscular route. Following 15, 30, 60 , and 120 minutes of treatments, PD and IOP were assessed as aforementioned.

Data were tested for normal distribution using the Shapiro-Wilk test. Differences between right and left eyes were not observed by the paired $t$-test; therefore, the mean between both eyes were 
considerate for statistical analysis. For both PD and IOP values, comparisons among periods within each group were performed using one-way analysis of variance for repeated measures, followed by the multiple comparison test of Tukey. Two-way analysis of variance followed by the Bonferronif adjustment test were used for comparisons between groups. On all occasions, a $\mathrm{P}$ value $<0.05$ was considered statistically significant. Results are shown as mean \pm standard error of mean.

\section{RESULTS}

\section{Pupil diameter}

PD values did not differ significantly between groups at baseline $(\mathrm{P}=0.58)$. When comparing among periods, it was observed that even though PD had increased by $0.90 \mathrm{~mm}$ in the first 15 minutes of evaluation in the $A G$, such difference was not significant $(\mathrm{P}=0.16)$ (Table 1, Figure 1A). Afterwards, the PD in the AG continued to decrease significantly until the last time point $(\mathrm{P}=0.02)$; however, in this last period of evaluation, such parameter did not differ from baseline $(\mathrm{P}=0.89)$ (Table 1, Figure 1A). When compared to baseline, $P D$ values in the TG increased significantly from time point 15 until the end of the experiment $(\mathrm{P}<0.001)$; notwithstanding, significant reductions of $\mathrm{PD}$ values were observed in the same group from time point 30 to $120(\mathrm{P}=0.01)$. In the ATG, PD increased significantly only from time point 30 to 120 when compared to baseline $(\mathrm{P}<0.001)$; but significant differences from time point 30 to 120 were not seen $(\mathrm{P}=0.71)$ (Table 1 , Figure 1A). In comparisons between groups, despite at time point $15 \mathrm{PD}$ values of the TG and the ATG were higher than that of the AG, such differences did not reach statistical significance $(\mathrm{P}>0.05)$ (Table 1 , Figure 1A). Nonetheless, from the second until the last time point of evaluation, PD values in the TG and ATG remained significantly higher than those in the AG $(\mathrm{P}<0.05)$ (Table 1, Figure 1A).

\section{Intraocular pressure}

IOP values did not differ significantly between groups at baseline ( $\mathrm{P}=0.91)$. When comparing among periods, it was observed that in the AT $(\mathrm{P}=0.11)$ and the ATG $(\mathrm{P}=0.13)$, such parameter did not change (Table 1, Figure 1B). IOP increased by $3.30 \mathrm{~mm}$ in the first 15 minutes of evaluation in the TG, but the difference was not significant compared to baseline $(\mathrm{P}=0.05)$ and the other time points $(\mathrm{P}>0.05)$ (Table 1, Figure 1B). In comparisons between groups, the TG had higher IOP values at 30 and 60 minutes, compared to the AG (2.15 and $2.20 \mathrm{mmHg}$, respectively) and the ATG (3.35 and $3.00 \mathrm{mmHg}$, respectively), but such differences were not statistically significant $(\mathrm{P}>0.05)$ (Table 1, Figure 1B).

\section{DISCUSSION}

The recommended doses of tramadol and acepromazine for cats range from 2 to $6 \mathrm{~kg}^{-1}$ and 0.05 to $0.1 \mathrm{mg} \mathrm{kg}^{-1}$, respectively. Thus, we chose to use doses close to its inferior limits, to minimize adverse effects of both drugs (CASSU et al., 2005).

The present study showed that $3 \mathrm{mg} \mathrm{kg}^{-1}$ of tramadol increased PD values from baseline by $29.38 \%$. In the cats of our study, mydriasis was observed after 15 minutes of the administration of tramadol and was sustained throughout the experiment. In humans, changes in PD were observed only after 120 minutes of the administration of tramadol (KNAGGS et al.,

Table 1 - Mean values \pm standard error of pupil diameter $(\mathrm{mm})$ and intraocular pressure $(\mathrm{mmHg})$ before (baseline) and after $15,30,60$ and 120 minutes of the intramuscular administration of acepromazine, tramadol and acepromazine/tramadol in young healthy cats.

\begin{tabular}{|c|c|c|c|c|c|}
\hline Variables & Baseline & 15 minutes & 30 minutes & 60 minutes & 120 minutes \\
\hline \multicolumn{6}{|c|}{ } \\
\hline Acepromazine & $9.31 \pm 0.55$ & $10.21 \pm 0.52$ & $9.94 \pm 0.56$ & $9.74 \pm 0.55$ & $8.97 \pm 0.61$ \\
\hline Tramadol & $9.29 \pm 0.60$ & $11.67 \pm 0.39 \mathrm{aA}$ & $12.37 \pm 0.27 \mathrm{aA}$ & $12.27 \pm 0.47 \mathrm{aA}$ & $11.76 \pm 0.31 \mathrm{aA}$ \\
\hline Acepromazine/tramadol & $10.02 \pm 0.52$ & $11.31 \pm 0.37$ & $11.80 \pm 0.27 \mathrm{aA}$ & $11.59 \pm 0.29 \mathrm{aA}$ & $11.57 \pm 0.28 \mathrm{aA}$ \\
\hline \multicolumn{6}{|c|}{ 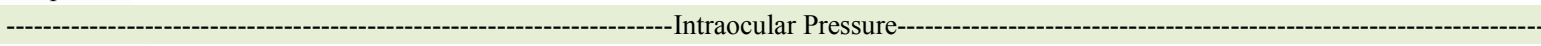 } \\
\hline Acepromazine & $18.65 \pm 1.18$ & $19.05 \pm 1.71$ & $19.05 \pm 1.59$ & $17.00 \pm 1.00$ & $16.55 \pm 0.66$ \\
\hline Tramadol & $17.90 \pm 0.82$ & $19.85 \pm 0.85$ & $21.20 \pm 1.14$ & $19.20 \pm 0.87$ & $16.70 \pm 0.42$ \\
\hline Acepromazine/tramadol & $18.50 \pm 1.67$ & $17.90 \pm 1.48$ & $17.85 \pm 1.63$ & $16.20 \pm 1.32$ & $16.10 \pm 1.00$ \\
\hline
\end{tabular}

Lowercase letters differ significantly from baseline in each group $(\mathrm{P}<0.05)$. Uppercase letters differ significantly from the acepromazine group $(\mathrm{P}<0.05)$. 


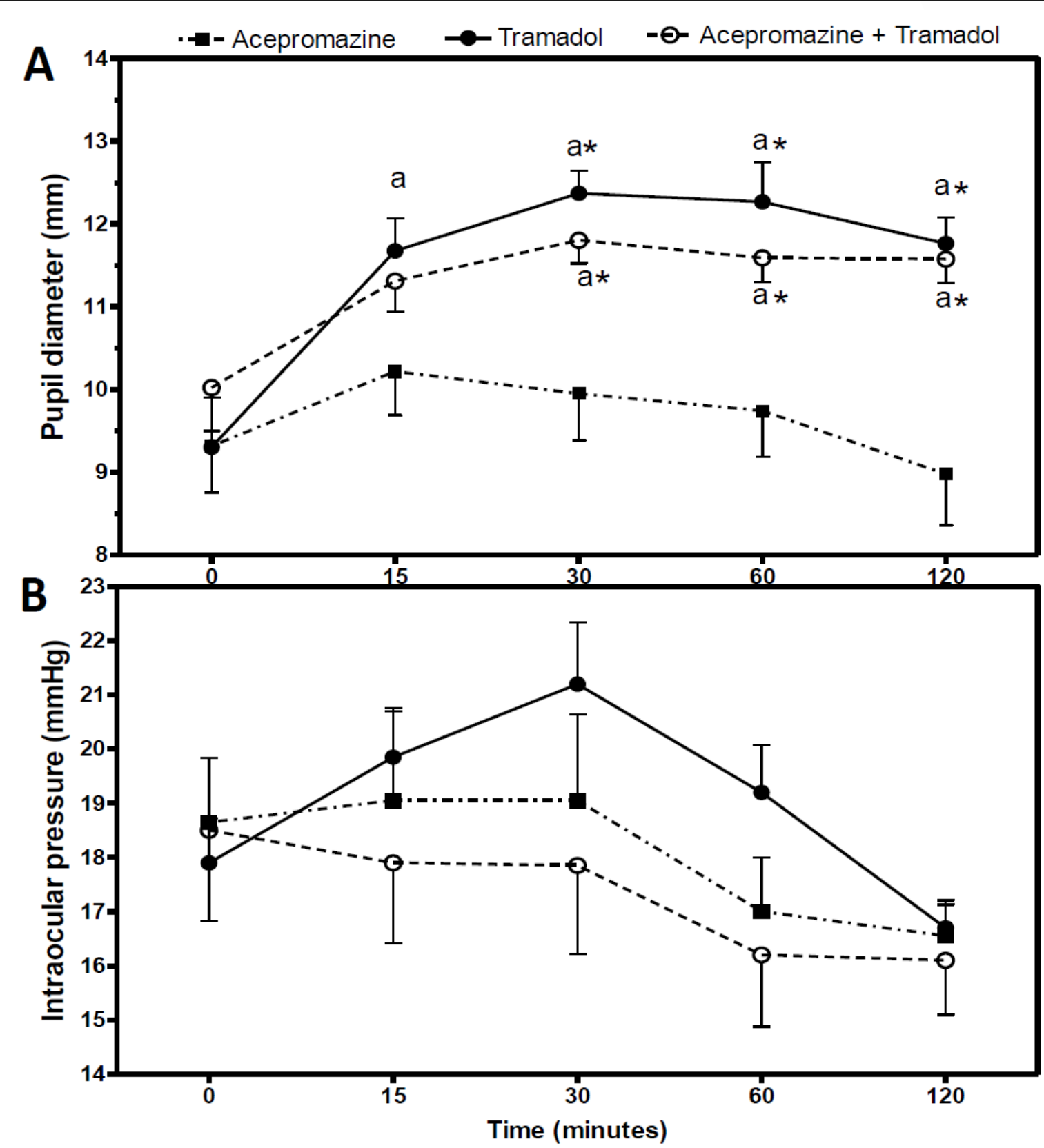

Figure 1 - Mean values \pm standard error of pupil diameter $(\mathrm{mm})(\mathrm{A})$ and intraocular pressure (mmHg) (B) before (baseline) and after 15, 30, 60 and 120 minutes of the intramuscular administration of acepromazine, tramadol and the combination acepromazine and tramadol in young healthy cats. Letter "a" differs significantly from baseline in each group $(\mathrm{P}<0.05)$. "Differs significantly from the acepromazine group $(\mathrm{P}<0.05)$.

2004; MATOUSKOVA et al., 2011; STOOPS et al., 2013); whereas in dogs treated with different doses of tramadol, PD did not change significantly during 60 minutes of evaluation (SANTOS et al., 2013; RUIZ et al., 2015). In humans, the pupillary response to tramadol is influenced by the genotype CYP2D6, which encodes isoenzymes that metabolize tramadol to its active metabolite (M1) (MATOUSKOVAet al., 2011). Thus, individuals that do not express such genotype tend to develop mydriasis when treated with tramadol; while the ones that express CYP2D6, miosis was observed (PEREZ et al., 2016). Regarding the pharmacokinetics 
of tramadol, it has been suggested that cats may be somewhat deficient in the $\mathrm{P} 450$ enzymes responsible for demethylation of this drug, which may contribute to the increased half-life and clearance of tramadol observed in this species (PYPENDOP \& ILKIW, 2008). As a result of impaired glucuronidation in this species, the isoform M1 tends to persist for longer periods in cats than in dogs (CAGNARDI et al., 2011). Additionally, the rate of M1 formation by liver microsomes of cats are 3.9 times faster than that observed in dogs (PEREZ et al., 2016). The significant reduction of PD values observed from the middle time point to the end of our experiment suggested that tramadol is able to sustain mydriasis in cats for at least 2 hours. However, more studies need to be undertaken in order to investigate possible correlations between pharmacokinetic data and PD, following the administration of tramadol in cats.

Some mechanisms may be suggested in order to explain the tramadol-induced mydriasis in cats of our study. Opiate-induced mydriasis in the cat comes partially from peripheral mechanisms and a large part is centrally mediated (SHARP, 1991). SHARP (1991) observed that separate neural mechanisms control the pupillary components and that $\mu$-opioid receptors are more involved in mediating opiate-induced mydriasis in the cat. Compounds that cause the blockade of noradrenaline reuptake such as tramadol are known to stimulate the dilatation of pupil through indirect stimulation of $\alpha$-adrenergic receptors and an increase in sympathetic tone (MATOUSKOVA et al., 2011). However, the extent to which opiates produce mydriasis or miosis by acting directly on the pupillo-constrictor neurons or indirectly through arousal mechanisms has never been determined in the cat.

It has been reported that acepromazine alone or its association with hydromophone or tramadol caused significant miosis in dogs (STEPHAN et al., 2003; SANTOS et al., 2013). In our research, despite PD had increased by $0.90 \mathrm{~mm}$ in the first 15 minutes of evaluation, followed by a significant reduction in last time point, such parameter did not differ significantly when compared to baseline values. Differently from what has been reported in dogs, the association acepromazine/ tramadol also induced significant mydriasis in cats of our study (SANTOS et al., 2013). Such findings suggested that tramadol plays a more important role in PD than acepromazine.

Regarding IOP, the three protocols tested herein did not change significantly this parameter during the 120 minutes of evaluation. Likewise, such parameter did not change during the 60 minutes of evaluation in dogs treated with 4 and $6 \mathrm{~mm} \mathrm{~kg}^{-1}$ of tramadol (RUIZ et al., 2015). CHU et al. (2014) have shown that mice treated with low doses of acepromazine maintain IOP values similar to those values recorded in controls for 120 minutes. However, the same researchers have reported that lower IOP readings are associated with higher doses of this agent in mice (CHU et al., 2014). In the present research, acepromazine alone or associated to tramadol did not alter IOP values throughout the experiment. Other studies conducted in dogs have reported that the association of acepromazine with butorphanol or hydromorphone did not induce changes in IOP before, and during inhalant anesthesia (TAMURA et al., 2002; STEPHAN et al., 2003); whereas in another research, also conducted in dogs, the combination of acepromazine with pethidine increased IOP at some time points during the anesthetic procedure (TAMURA et al., 2002).

\section{CONCLUSION}

The results of this study suggest that tramadol alone or in association with acepromazine caused significant mydriasis and did not change IOP values in normal cats. Therefore, it may be considered a satisfactory pre-anesthetic combination for ophthalmic surgery in cats. However, further studies are warranted on the use of such protocols in cats with ophthalmic diseases undergoing ocular or intraocular surgery.

\section{SOURCES OF AQUISITION}

a - Medidor Multifunção ITPM-600, Instrutemp, Brasil.

b - PaquímetroInox 150mm Digital, Lee Tools, Brasil.

c - Tono-Pen ${ }^{\circledR}$ XL, Medtronic Solan, EUA.

d - Acepran ${ }^{\circledR} 0.2 \%$, Vetnil, Brasil.

e - Cloridrato de Tramadol 50mg mL $\mathrm{mL}^{-1}$, União Química, Brasil

f - Prisma 7.0 ${ }^{\circledR}$, Graphpad Software Inc. San Diego, EUA.

\section{BIOETHICS AND BIOSSECURITY COMMITTEE APPROVAL}

This study was approved by the institutional Committee for Ethics in the Use of Animals (Universidade Federal do Mato Grosso) on September 02, 2016 (protocol \# 23108.165541/2016-55).

\section{REFERENCES}

CAGNARDI,P.etal.Pharmacokinetics,intraoperativeeffectandpostoperative analgesia oftramadol in cats. Research in Veterinary Science, v.90, p.503-509, 2011. Available from: <http://www.sciencedirect.com/science/ article/pii/S0034528810002511>. Accessed: 20, jan. 2017. doi: 10.1016/j. rvsc.2010.07.015. 
CASSU, R.N. et al. Avaliação do efeito sedativo e da dose de indução anestésica do propofol sob diferentes medicações pré-anestésicas em gatos. Revista Clínica Veterinária, v.58, p.68-76, 2005. Available from: <http://www.revistaclinicaveterinaria.com. br/edicao/2005/setembro-outubro.html>. Accessed: 23, jan. 2017.

CLARK, J.S. et al. Evaluation of topical nalbuphine or oral tramadol as analgesics for corneal pain in dogs: a pilot study. Veterinary Ophthalmology, v.14, n.6, p.358-364, 2011. Available from: <http://onlinelibrary.wiley.com/doi/10.1111/j.1463-5224.2011.00883.x/abstract>. Accessed: 23, may 2017. doi: 10.1111/j.1463-5224.2011.00883.x.

CHU, E.R. et al. Intraocular pressure measurement in acepromazinesedated mice. Clinical\& Experimental Ophthalmology, v.42, p.395-397, 2014. Available from: <http://onlinelibrary.wiley.com/ doi/10.1111/ceo.12157/full>. Accessed: 20, jan. 2017. doi: 10.1111/ ceo. 12157 .

GELATT, K.N. Anesthesia for ophthalmic surgery. In: GELATT, K.N.; GELATT, J.P. Veterinary Ophthalmic Surgery. 3.ed. Oxford: Saunders Elsevier, 2011. Chap. 3, p.37-49.

KNAGGS, R.D. et al. The pupillary effects of intravenous morphine, codeine, and tramadol in volunteers. Anesthesia \& Analgesia, v.99, p.108-112, 2004. Available from: <www.com/anesthesia-analgesia/ pages/articleviewer.aspx ?year $=2004 \&$ issue $=07000 \&$ article $=00$ 023\&type $=$ abstract $>$. Accessed: 07, jan. 2017. doi: 10.1213/01. ANE.0000116924.16535.BA.

MALMASI, A.; GHAFFARI, M.S. Lack of effects of intramuscular medetomidine on intraocular pressure in clinically normal cats. Journal of Feline Medicine and Surgery, v.18, n.4, p.315-317, 2016. Available from: $<$ http://journals.sagepub.com/doi/abs/10.1177/109861 2X15583343?url_ver=Z39.88-2003\&rfr_id=ori\%3Arid\%3Acrossref. org\&rfr dat $=$ cr pub\%3Dpubmed\&>. Accessed: 13 , jan. 2017. doi: $10.1177 / 1098612 X 15583343$.

MATOUSKOVA, O. et al. Pupillometry in healthy volunteers as a biomarker of tramadol efficacy. Journal of Clinical Pharmacy and Therapeutics, v. 36, p.513-517, 2011. Available from: $<$ https:// www.ncbi.nlm.nih.gov/pubmed/21729116>. Accessed: 20, jan. 2017. doi: 10.1111/j.1365-2710.2010.01203.x.

MAYORDOMO-FEBER et al. Effects of morphine-alfaloxonemidazolam premedication, alfaloxone induction and sevoflurane maintenance on intraocular pressure and tear production in dogs. Veterinary Record, 2017, prelo Available from: <http:// veterinaryrecord.bmj.com/content/early/2017/01/06/vr.104040. full $>$. Accessed: 20, jan. 2017. doi: 10.1136/vr.104040.

PEREZ, T.E. et al. Tramadol metabolism to O-desmethyltramadol (M1) and N-desmethyl-tramadol (M2) bydoglivermicrosomes: speciescomparisonandidentificationofresponsiblecaninecytocrome P-450 (CYPs). Drug Metabolism and Disposition, v.44, n.12, p.1963-1972, 2016. Available from: <http://dmd.aspetjournals.org/ content/early/2016/10/06/dmd.116.071902>. Accessed: 20, jan. 2017. doi: $10.1124 /$ dmd.116.071902.

PYPENDOP, B.H.; ILKIW, J.E. Pharmacokinetics of tramadol, and its metabolite O-desmethyl-tramadol, in cats. Journal of Veterinary Pharmacology and Therapeutics, v. 31, p.52-59, 2008. Available from: <https://www.ncbi.nlm.nih.gov/pubmed/18177319>. Accessed in: 20, jan. 2017. doi: 10.1111/j.1365-2885.2007.00921.x.

RUIZ, T. et al. Effects of tramadol on tear production, intraocular pressure, and pupil size in dogs: clinical study. Ciência Rural, v. 45, n.4, p.724-729, 2015. Available from: <http://www.scielo.br/scielo. php?script=sci_arttext\&pid=S0103-84782015000400724\&lng=en \&nrm=iso\&tlng=en>. Accessed: 21, jan. 2017. doi: 10.1590/0103$8478 \mathrm{cr} 20140826$

SANTOS, P.H.A. et al. Comparisonofpupildiameterand tear production in dogstreatedwithacepromazine, tramadolandtheircombination. Revista Ceres, v.60, n.2, p.166-172, 2013. Available from: $<$ http://www.scielo.br/ pdf/rceres/v60n2/v60n2a04.pdf $>$. Accessed: 20, jan. 2017.

SHARP, L.G. Separate neural mechanisms mediate sufentanil-induced pupillary responses in the cat. Journal of Pharmacology and Experimental Theraputics, v.256, n.3, p.845-849, 1991. Available from: <http://jpet. aspetjournals.org/content/256/3/845.long $>$. Accessed: 20, jan. 2017.

STEAGALL, P.V.M. et al. Antinociceptive effects of tramadol and acepromazinein cats. Journal of FelineMedicineandSurgery, v.10,p.24-31, 2008.Availablefrom: $<$ http://www.sciencedirect.com/science?_ob=MImg\&_ imagekey $=$ B6WJC-4PK8BB9-1-1\&_cdi $=6875 \&$ \& user $=10 \&$

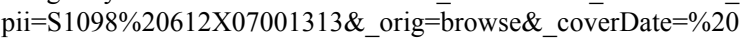
02/29/2008\&_sk=999899998\&view=c\&wchp $=d G L b V z W-z S k W b \& m d 5=$ 3147618ea27aa6a67d9f19c243f62f43\&ie=/sdarticle.pdf $>$. Accessed: 20, jan. 2017. doi: 10.1016/j.jfms.2007.06.009.

STEPHAN, D.D. et al. Changes in intraocular pressure and pupil size following intramuscular administration of hydromorphone hydrochloride and acepromazine in clinically normal dogs. Veterinary Ophthalmology, v.6, p.73-76, 2003. Available from: <http:// onlinelibrary.wiley.com/doi/10.1046/j.1463-5224.2003.00273.x/ full $>$.Accessed: 20, jan. 2017. doi: 10.1046/j.1463-5224.2003.00273.x.

STOOPS, W.W. et al. Miotic and subject-rate effects of therapeutic doses of tapentadol, tramadol, and hydromorphone in occasional opioid users. Psycopharmacology, v.228, p.255-262, 2013. Available from: <http://link.springer.com/article/10.1007/s00213-013-3031-y>. Accessed: 20, jan. 2017. doi: 10.1007/s00213-013-3031-y.

TAMURA, E.Y. et al. Effects of two pre-anesthetic regimens for ophthalmic surgery on intraocular pressure and cardiovascular measurements in dogs. Veterinary Therapeutics: Research in Applied Veterinary Medicine, v.3, n.1, p.81-87, 2002. Available from: <https://www. ncbi.nlm.nih.gov/pubmed/12050831>. Accessed: 25, Jan. 2017. 